\title{
Regulation of angiotensin-(1-7) and angiotensin II type 1 receptor by telmisartan and losartan in adriamycin-induced rat heart failure
}

Wen-na ZONG\#, Xiao-hui YANG\#, Xiu-mei CHEN, Hong-juan HUANG, Hong-jian ZHENG, Xiao-yi QIN, Yong-hong YONG, Kejiang CAO, Jun HUANG, Xin-zheng LU*

Department of Cardiology, First Affiliated Hospital, Nanjing Medical University, Nanjing 210029, China

Aim: To investigate the possible effects of telmisartan and losartan on cardiac function in adriamycin (ADR)-induced heart failure in rats, and to explore the changes in plasma level of angiotensin-(1-7)[Ang-(1-7)] and myocardial expression of angiotensin II type 1/2 receptors $\left(A T_{1} R / A T_{2} R\right)$ and Mas receptor caused by the two drugs.

Methods: Male Sprague-Dawley rats were randomly divided into 4 groups: the control group, ADR-treated heart failure group (ADR-HF), telmisartan plus ADR-treated group (Tel+ADR) and losartan plus ADR-treated group (Los+ADR). ADR was administrated (2.5 mg/kg, ip, 6 times in 2 weeks). The rats in the Tel+ADR and Los+ADR groups were treated orally with telmisartan (10 mg/kg daily po) and losartan (30 mg/kg daily), respectively, for 6 weeks. The plasma level of Ang-(1-7) was determined using ELISA. The mRNA and protein expression of myocardial Mas receptor, $\mathrm{AT}_{1} \mathrm{R}$ and $\mathrm{AT}_{2} \mathrm{R}$ were measured using RT-PCR and Western blotting, respectively.

Results: ADR significantly reduced the plasma level of Ang-(1-7) and the expression of myocardial Mas receptor and myocardial $A T_{2} R$, while significantly increased the expression of myocardial $A_{1}{ }_{1} \mathrm{R}$. Treatment with telmisartan and losartan effectively increased the plasma level of Ang-(1-7) and suppressed myocardial $A T_{1} R$ expression, but did not influence the expression of Mas receptor and $A T_{2} R$. Conclusion: The protective effects of telmisartan and losartan in ADR-induced heart failure may be partially due to regulation of circulating Ang-(1-7) and myocardial $\mathrm{AT}_{1} \mathrm{R}$ expression.

Keywords: angiotensin-(1-7); Mas; angiotensin I receptor; angiotensin II receptor; adriamycin; heart failure; telmisartan; losartan

Acta Pharmacologica Sinica (2011) 32: 1345-1350; doi: 10.1038/aps.2011.96; published online 3 Oct 2011

\section{Introduction}

Adriamycin (ADR) is an anthracycline antibiotic commonly used in the treatment of a wide range of cancers, including hematological malignancies, many types of carcinomas, and soft tissue sarcomas. Importantly, the use of adriamycin can cause acute and chronic side effects. The chronic side effects are represented by the development of cardiomyopathy and ultimately, irreversible congestive heart failure ${ }^{[1,2]}$. Great effort has been expended in preventing or mitigating the cardiotoxic side effects of $\mathrm{ADR}^{[3-7]}$; however, the mechanisms underlying ADR-induced heart failure are not fully understood.

The renin-angiotensin system (RAS) is one of the key regulators of blood pressure and cardiovascular disease ${ }^{[8-10]}$ and involves several enzymes and receptors: renin, angiotensin

\footnotetext{
\# The first two authors contributed equally to this work.

* To whom correspondence should be addressed.

E-mail xzlu@njmu.edu.cn

Received 2010-12-31 Accepted 2011-06-21
}

II (Ang II), the Ang II type 1 receptor $\left(\mathrm{AT}_{1} \mathrm{R}\right)$, the Ang II type 2 receptor $\left(\mathrm{AT}_{2} \mathrm{R}\right)$ and the Mas receptor. Many reports have demonstrated the critical roles that these factors have in heart failure $^{[9]}$. Ang II is an oligopeptide that causes vasoconstriction, increased blood pressure, and release of aldosterone from the adrenal cortex, while $A_{1} R$ and $A_{2} R$ are the receptors for Ang II. $\mathrm{AT}_{1} \mathrm{R}$ mediates the major cardiovascular effects of Ang II, including vasoconstriction, increased vasopressin secretion, cardiac hypertrophy, cardiac contractility and extracellular matrix formation ${ }^{[9]}$. Conversely, effects mediated by $\mathrm{AT}_{2} \mathrm{R}$ include inhibition of cell growth, neuronal regeneration, cellular differentiation and possibly vasodilatation ${ }^{[9]}$. Angiotensin(1-7) [Ang-(1-7)] is a peptide formed from either Ang I or Ang $\mathrm{II}^{[9]}$. Ang-(1-7) is considered to be an important peptide fragment of the RAS, and it plays crucial roles that are often opposite from those of Ang $\mathrm{II}^{[11]}$. Ang-(1-7) can induce vasodilatation, diuresis and natriuresis, anti-hypertrophy, antiproliferation, anti-fibrosis and stimulate bradykinin and NO release via binding to the Mas receptor ${ }^{[12]}$. The Mas receptor is 
an oncogene as well as a receptor for Ang-(1-7) ${ }^{[13]}$. In a previous work, Mas receptor-deficient mice showed higher blood pressure values, impaired endothelial function, decreased NO production and lower endothelial NO synthetase expression ${ }^{[14]}$, indicating that the Ang-(1-7)/Mas receptor axis plays an important role in cardioprotective and antihypertensive effects. Importantly, Ang-(1-7) can prevent heart failure after myocardial ischemia ${ }^{[15]}$.

Some recent studies have reported that angiotensin converting enzyme inhibitors (ACEIs) and angiotensin receptor blockers (ARBs), two classes of drugs that target RAS, may prevent ADR-induced cardiotoxicity ${ }^{[16-19]}$. However, the underlying mechanisms are largely unclear. In the present study, we investigated the regulation of two ARBs (telmisartan and losartan) on plasma Ang-(1-7) levels and the mRNA and protein expression of the myocardial $\mathrm{AT}_{1} \mathrm{R}, \mathrm{AT}_{2} \mathrm{R}$ and Mas receptors in ADR-induced heart failure.

\section{Materials and methods Animals}

A total of 70 male Sprague-Dawley (SD) rats weighing $(217 \pm 18) \mathrm{g}$ were obtained from Slack Laboratory Animal Co Ltd in Shanghai (SCXK: 2008-0004, China). All experimental procedures were conducted according to the Institutional Animal Care guidelines and approved ethically by the Administration Committee of Experimental Animals, Jiangsu Province, China.

\section{Drugs}

ADR, telmisartan and losartan were obtained from Hisun Pharmaceutical Co Ltd (Zhejiang, China), Novartis (Switzerland) and MSD Pharmaceutical Co Ltd (Hangzhou, China), respectively.

\section{Experimental protocol}

Rats were randomly divided into four groups: (1) the control group $(n=10$, intraperitoneally injected an equal volume of normal saline); (2) the ADR-treated heart failure group (ADR-HF, $n=20$, intraperitoneally injected ADR, a $2.5 \mathrm{mg} / \mathrm{kg}$ dose administered 6 times in 2 weeks, resulting in a cumulative dose of $15 \mathrm{mg} / \mathrm{kg}$ ); (3) the ADR plus telmisartan group (Tel+ADR, $n=20$, intraperitoneally injected ADR as in the ADR-HF group and administered telmisartan $10 \mathrm{mg} / \mathrm{kg}$ per day orally for 6 weeks, for a cumulative dose of $420 \mathrm{mg} / \mathrm{kg}$ ); and (4) the ADR plus losartan group (Los+ADR, $n=20$, intraperitoneally injected ADR as in the ADR-HF group and administered Los $30 \mathrm{mg} / \mathrm{kg}$ per day orally for 6 weeks, for a cumulative dose of $1260 \mathrm{mg} / \mathrm{kg}$ ). During the treatment period, body weights of the rats were measured every three days, and the doses of ADR, telmisartan or losartan were adjusted according to the change in body weight. The death of animals was recorded daily.

\section{Echocardiography}

Four weeks after the last injection, the cardiac function of the rats was evaluated by transthoracic echocardiography (Vivid 7, General Electric Co) with a 10-MHz linear-array transducer as reported previously ${ }^{[20]}$. Briefly, rats were weighed and anesthetized using $10 \%$ chloral hydrate intraperitoneally (30 $\mathrm{mg} / \mathrm{kg}$ ) and placed on a warm blanket. The cardiac longaxis and short-axis views were obtained in the 2-dimensional mode, and M-mode tracings were recorded. Left ventricular internal dimension systole (LVIDs), left ventricular internal dimension diastole (LVIDd) and left ventricular ejection fraction (LVEF) were recorded in the M-mode tracings by the same expert, and all measurements were performed by an observer blinded to the treatments. We defined heart failure in this rat model according to the cardiac function as assessed by echocardiography.

\section{Plasma Ang-(1-7) assay}

After echocardiography, the abdominal aorta was carefully isolated, and $5 \mathrm{~mL}$ of arterial blood was collected into tubes containing disodium EDTA. Then, the plasma was obtained and stored at $-80^{\circ} \mathrm{C}$ until use. Plasma Ang-(1-7) was assayed using an ELISA kit (Catalog №: F1763, Xitang Biotechnology Co, Ltd, Shanghai, China) with a microplate reader (Clinibio128C). The optical density at $450 \mathrm{~nm}$ was obtained within $30 \mathrm{~min}$. The standard curve was constructed by plotting the mean absorbance obtained for each reference standard against its concentration ${ }^{[21]}$. Using the mean absorbance value for each sample, the corresponding concentration was determined from the standard curve.

\section{RNA isolation and RT-PCR}

After blood collection, deeply anesthetized rats were sacrificed. Hearts were isolated and rinsed in saline. The cardiac ventricles were separated from the atria, weighed, cut into two segments, frozen in liquid nitrogen and stored at $-70^{\circ} \mathrm{C}$. Total RNA in the aorta from the four groups of rats was extracted using Trizol reagent (Invitrogen, USA) ${ }^{[22]}$. The RNA concentration was determined by the absorbance at $260 \mathrm{~nm}$. The mRNA expression of the myocardial Mas receptor, $\mathrm{AT}_{1} \mathrm{R}$ and $\mathrm{AT}_{2} \mathrm{R}$ was determined by RT-PCR (TaKaRa Biotechnology Co Ltd, Dalian, China). The reaction conditions of RT-PCR were as follows: $30^{\circ} \mathrm{C}$ for $10 \mathrm{~min}, 47^{\circ} \mathrm{C}$ for $30 \mathrm{~min}, 99^{\circ} \mathrm{C}$ for $5 \mathrm{~min}$ and $5^{\circ} \mathrm{C}$ for $5 \mathrm{~min}$. After reverse transcription, the cDNA was denatured at $94^{\circ} \mathrm{C}$ for $2 \mathrm{~min}$ and subjected to 35 cycles of PCR at $94^{\circ} \mathrm{C}$ for $30 \mathrm{~s}, 60^{\circ} \mathrm{C}$ for $30 \mathrm{~s}$ and $72^{\circ} \mathrm{C}$ for $1 \mathrm{~min}$ (Mas receptor) and 35 cycles of PCR at $94^{\circ} \mathrm{C}$ for $30 \mathrm{~s}, 59^{\circ} \mathrm{C}$ for $30 \mathrm{~s}$ and $72^{\circ} \mathrm{C}$ for $1 \mathrm{~min}\left(\mathrm{AT}_{1} \mathrm{R}, \mathrm{AT}_{2} \mathrm{R}\right.$, and $\beta$-actin), followed by extension at $72^{\circ} \mathrm{C}$ for $7 \mathrm{~min}$. The selected primers designed for Mas receptor, $\mathrm{AT}_{1} \mathrm{R}, \mathrm{AT}_{2} \mathrm{R}$, and $\beta$-actin were as follows: forward: 5'-ACTGCCGGGCGGTCATCATC-3', reverse: 5'-GGTGGAGAAAAGCAAGGAGC-3' for Mas receptor (263 bp); forward: 5'-GCCCTGGCTGATTTATGC-3', reverse: 5'-GGAAAGGGAACACGAAGC-3' for $\mathrm{AT}_{1} \mathrm{R}$; forward: $5^{\prime}$-TGGCTTGTCTGTC CTCAT-3', reverse: 5'-AGACTTGGTCACGG GTAA-3' for $\mathrm{AT}_{2} \mathrm{R}$; forward: 5'-AAGACCTGTACGCCAACACAGT-3', reverse: $5^{\prime}$-AGAAGCATTTGCGGTGGACGAT-3' for $\beta$-actin. 


\section{Western blotting analysis}

Western blotting analysis was performed as described previously ${ }^{[23,24]}$. Protein $(20 \mu \mathrm{g})$ extracted from the heart tissues from the four groups was subjected to $10 \%$ polyacrylamide gel electrophoresis and then transferred onto PVDF membranes. The membranes were probed using primary antibodies against the Mas receptor, $\mathrm{AT}_{1} \mathrm{R}$ and $\mathrm{AT}_{2} \mathrm{R}$ (all from Santa Cruz Biotechnology, USA) overnight at $4{ }^{\circ} \mathrm{C}$, followed by horseradish peroxidase-conjugated secondary antibody (Santa Cruz Biotechnology, USA) for $2 \mathrm{~h}$ at room temperature. Glyceraldehyde 3-phosphate dehydrogenase (GAPDH) (Kang Chen Bio-Tech, Shanghai, China) was used as the loading control. Antibody binding was visualized using the ECL system (Yuehua Medical Instrument Co Ltd, Guangdong, China), and the amount of Mas receptor, $A_{1} R$ and $A_{2} R$ were expressed relative to that of $\mathrm{GAPDH}^{[22]}$.

\section{Statistical analysis}

Results are presented as the meantstandard deviation (SD). Comparisons between two groups were assessed by Student's $t$-test, and comparisons of three or more groups were performed using one-way ANOVA followed by LSD post-hoc using SPSS 11.5 software (Chicago, IL, USA). Statistical significance was set at $P<0.05$.

\section{Results}

\section{Heart failure model}

Body weights were comparable among the four groups at the start of the study. However, after treatment, the weight gain was less in the ADR-HF group than in controls $(304.4 \pm 19.8 \mathrm{~g}$ vs $408.6 \pm 12.8 \mathrm{~g}, P<0.01$, Table 1, Figure 1). The body weights of the Tel+ADR and Los+ADR groups were higher than that of ADR-HF group ( $P<0.01$, Table 1, Figure 1$)$, although these were still lower than that of the control $(P<0.01$, Table 1, Figure 1). No significant differences between the weights of the Tel+ADR and Los+ADR groups were observed $(P>0.05$, Table 1 , Figure 1). At the end of the treatment (4 weeks after the last injection), the numbers of rats in each group were as follows:

Table 1. Weight and cardiac functional parameters at the end of the study (week 6 ) in four groups. Data are expressed as mean \pm SD. ${ }^{b} P<0.05$, ${ }^{\mathrm{c}} P<0.01$ vs controls. ${ }^{\mathrm{e}} P<0.05,{ }^{\mathrm{f}} P<0.01$ vs adriamycin-induced heart failure rats.

\begin{tabular}{lcccc}
\hline & $\begin{array}{c}\text { Controls } \\
(n=10)\end{array}$ & $\begin{array}{c}\text { ADR-HF } \\
(n=9)\end{array}$ & $\begin{array}{c}\text { Tel+ADR } \\
(n=12)\end{array}$ & $\begin{array}{c}\text { Los+ADR } \\
(n=13)\end{array}$ \\
\hline Weight $(\mathrm{g})$ & $408.6 \pm 12.8$ & $304.4 \pm 19.8^{\mathrm{b}}$ & $343.0 \pm 32.16^{\text {cf }}$ & $348.5 \pm 31.52^{\text {cf }}$ \\
LVIDs $(\mathrm{mm})$ & $3.64 \pm 0.33$ & $4.53 \pm 0.41^{\mathrm{e}}$ & $3.99 \pm 0.52^{\mathrm{e}}$ & $3.79 \pm 0.41^{\mathrm{e}}$ \\
LVIDd $(\mathrm{mm})$ & $5.79 \pm 0.48$ & $6.81 \pm 0.30^{\mathrm{e}}$ & $6.08 \pm 0.33^{\mathrm{e}}$ & $6.14 \pm 0.44^{\mathrm{e}}$ \\
LVEF $(\%)$ & $81.5 \pm 1.4$ & $63.8 \pm 4.4^{\mathrm{f}}$ & $72.5 \pm 1.8^{\text {cf }}$ & $73.9 \pm 2.7^{\text {cf }}$ \\
\hline
\end{tabular}

Controls=with normal saline injection; $A D R-H F=a d r i a m y c i n-i n d u c e d$ heart failure rats; Tel+ADR=telmisartan plus adriamycin-treated rats; Los+ADR=losartan plus adriamycin-treated rats. LVIDs=left ventri-cular internal dimension systole; LVIDd=left ventricular internal dimensi- on diastole; LVEF=left ventricular ejection fraction.

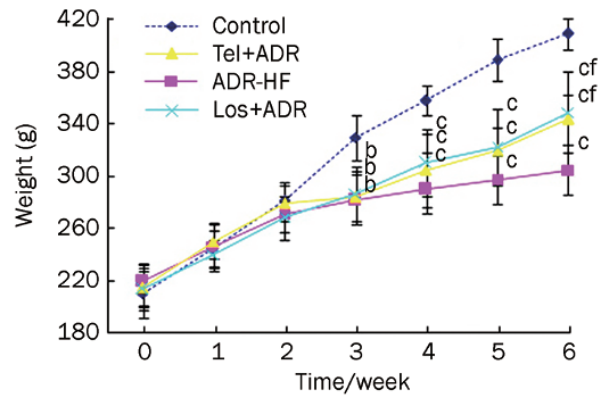

Figure 1. Changes in body weight in each group of rats. Controls=With normal saline injection; ADR-HF=Adriamycin-induced heart failure rats; Tel+ADR=Telmisartan plus Adriamycin-treated rats; Los+ADR=Losartan plus Adriamycin-treated rats. Data are expressed as mean $\pm S D$. ${ }^{b} P<0.05$, ${ }^{\mathrm{c}} P<0.01$ vs control group. ${ }^{\mathrm{f}} P<0.01$ vs ADR-HF group. Control, $n=10$; ADR$\mathrm{HF}, n=9$; Tel+ADR, $n=12$; and Los+ADR, $n=13$.

Control, $n=10$; ADR-HF, $n=9$; Tel+ADR, $n=12$; and Los+ADR, $n=13$.

The cardiac function of the rats was tested at the end of the treatment (Figure 2). Compared with the control group, LVIDs and LVIDd in ADR-HF group increased significantly, while LVEF decreased significantly (LVIDs: $4.53 \pm 0.41 \mathrm{~mm}$ vs $3.64 \pm 0.33 \mathrm{~mm}, P<0.05$; LVIDd: $6.81 \pm 0.30 \mathrm{~mm}$ vs $5.79 \pm 0.48 \mathrm{~mm}$, $P<0.05$; LVEF: $63.8 \% \pm 4.4 \%$ vs $81.5 \% \pm 1.4 \%, P<0.01$, Table 1$)$, indicating that cardiac function was significantly impaired in the ADR-HF group. Interestingly, while the LVEF of the ADR-HF was $63.8 \% \pm 4.4 \%$, those of the Tel+ADR and Los+ADR groups were $72.5 \% \pm 1.8 \%$ and $73.9 \% \pm 2.7 \%$, respectively, indicating a significant improvement $(P<0.01$, for both; Table 1). No significant differences in the LVIDs, LVIDd, and LVEF between the Tel+ADR and Los+ADR groups were observed (Table 1).

\section{Plasma levels of Ang-(1-7)}

The plasma level of Ang-(1-7) in the ADR-HF group was lower than that in the control group $(4.27 \pm 2.79 \mathrm{ng} / \mathrm{mL}$ vs $10.26 \pm 2.39 \mathrm{ng} / \mathrm{mL}, P<0.01$, Figure 3). Ang-(1-7) plasma levels of the Tel+ADR and Los+ADR groups were higher than that in ADR-HF group $(7.16 \pm 2.13 \mathrm{ng} / \mathrm{mL}$ vs $4.27 \pm 2.79 \mathrm{ng} / \mathrm{mL}$; $7.08 \pm 1.49 \mathrm{ng} / \mathrm{mL}$ vs $4.27 \pm 2.79 \mathrm{ng} / \mathrm{mL}$, both $P<0.05$, Figure 3 ) but were still lower than that in control group $(P<0.05$, Figure 3). There was no difference in plasma levels of Ang-(1-7) between the Tel+ADR and Los+ADR groups $(P>0.05$, Figure 3).

\section{Expression of the Mas receptor, $\mathrm{AT}_{1} \mathrm{R}$ and $\mathrm{AT}_{2} \mathrm{R}$ in the heart}

The expression levels of the Mas receptor, $A_{1} R$ and $A T_{2} R$ in cardiomyocytes were examined by RT-PCR analysis (Figure 4) and Western blotting (Figure 5). The mRNA and protein expression of the Mas receptor and $\mathrm{AT}_{2} \mathrm{R}$ were reduced in the ADR-HF group compared with the control group. Conversely, mRNA and protein expression of $\mathrm{AT}_{1} \mathrm{R}$ were increased. Treatment with telmisartan and losartan significantly suppressed the upregulation of $\mathrm{AT}_{1} \mathrm{R}$ but did not change the expression of 

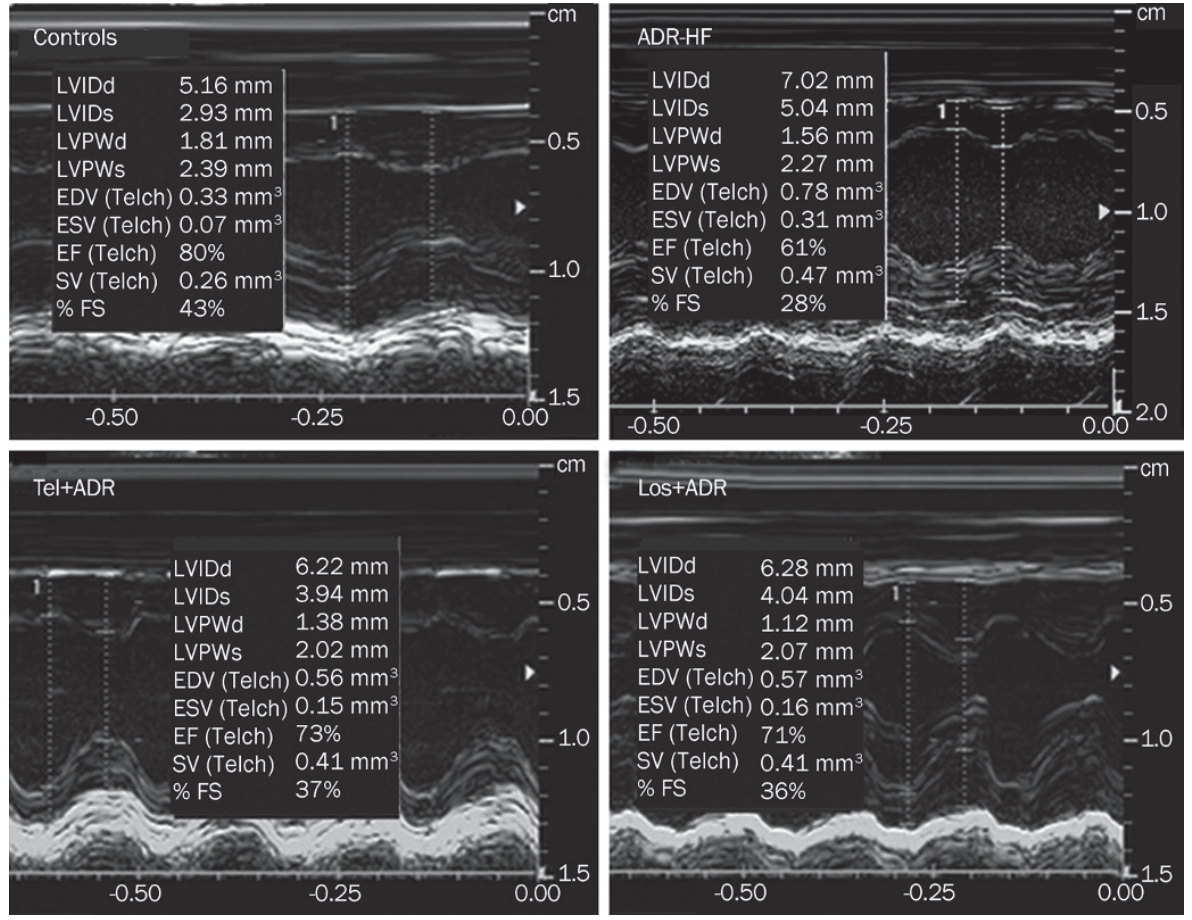

Figure 2. Transthoracic echocardiography to evaluate the cardiac function of rats. Controls=With normal saline injection; ADR$\mathrm{HF}=$ Adriamycin-induced heart failure rats; Tel+ADR $=$ Telmisartan plus Adriamycin-treated rats; Los+ADR=Losartan plus Adriamycintreated rats.

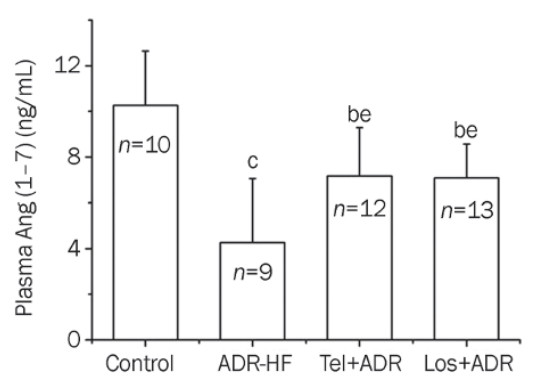

Figure 3. Plasma levels of angiotensin-(1-7) [Ang-(1-7)] were determined by ELISA in rats of the control, ADR-HF, Tel+ADR, and Los+ADR groups at the end of the study. Controls=With normal saline injection; ADR$\mathrm{HF}=$ Adriamycin-induced heart failure rats; Tel+ADR=Telmisartan plus Adriamycin-treated rats; Los+ADR=Losartan plus Adriamycin-treated rats. Mean \pm SD. ${ }^{b} P<0.05,{ }^{c} P<0.01$ vs controls. ${ }^{e} P<0.05$ vs ADR-HF.

the Mas receptor and $\mathrm{AT}_{2} \mathrm{R}$.

\section{Discussion}

In this study, we showed that ADR decreased plasma Ang(1-7) levels and myocardial Mas receptor and $\mathrm{AT}_{2} \mathrm{R}$ mRNA and protein expression, whereas it upregulated the myocardial mRNA and protein expression of $\mathrm{AT}_{1} \mathrm{R}$. Two kinds of ARBs, telmisartan and losartan, attenuated the ADR-induced reduction of plasma Ang-(1-7) and suppressed the ADR-induced enhancement of myocardial $\mathrm{AT}_{1} \mathrm{R}$ expression. Telmisartan and losartan did not change the expression of the Mas receptor and $\mathrm{AT}_{2} \mathrm{R}$.

Ang-(1-7) is produced from Ang I and Ang II. Under physi-
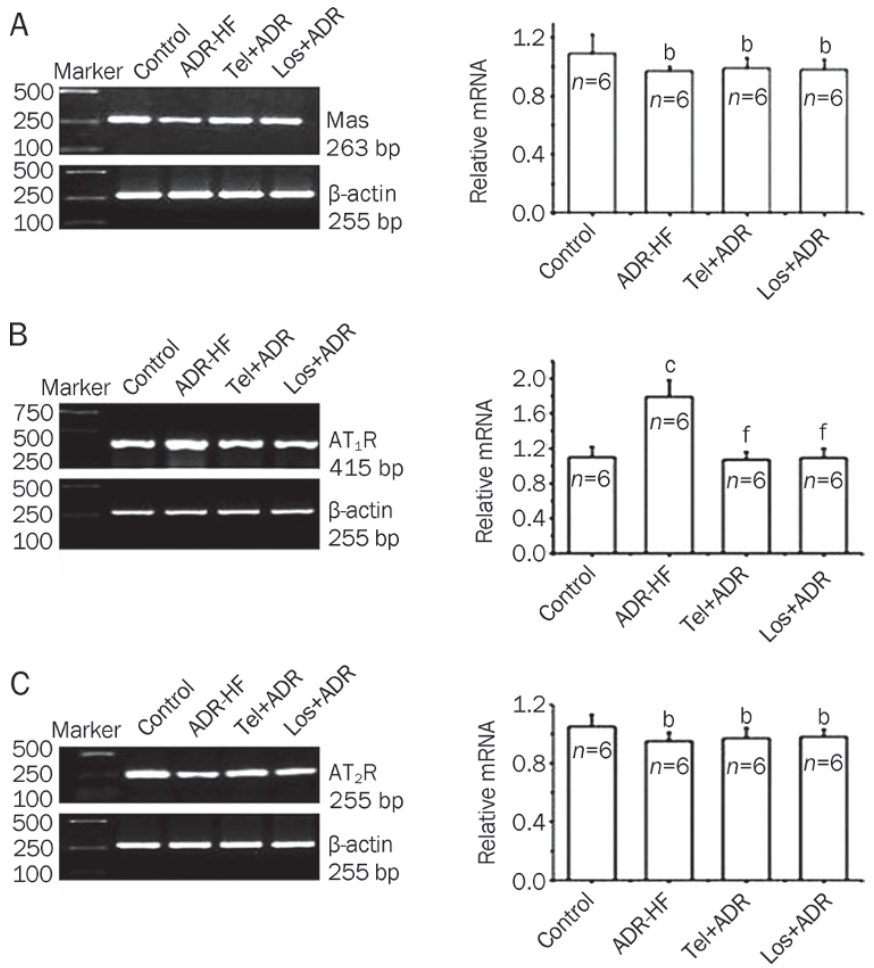

Figure 4. The mRNA expression levels of the Mas receptor $(A), A T_{1} R(B)$, and $A T_{2} R(C)$ in cardiac tissues at the end of the study were determined by RT-PCR. The amounts are expressed relative to the amount of $\beta$-actin. Controls=With normal saline injection; ADR-HF=Adriamycininduced heart failure rats; Tel+ADR=Telmisartan plus Adriamycin-treated rats; Los $+A D R=$ Losartan plus Adriamycin-treated rats. $n=6$. Mean $\pm S D$. ${ }^{\mathrm{b}} P<0.05,{ }^{\mathrm{c}} P<0.01$ vs control groups. ${ }^{\mathrm{f}} P<0.01$ vs ADR-HF. 

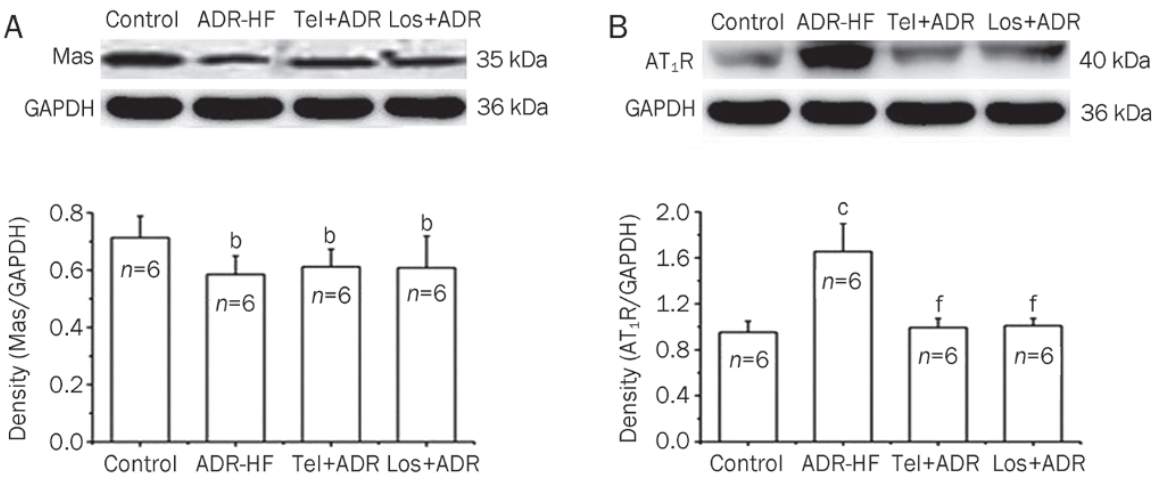

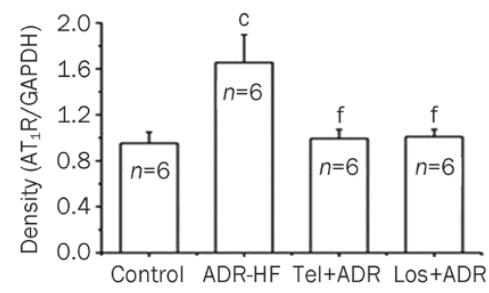

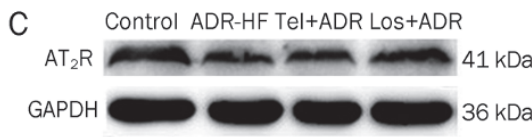

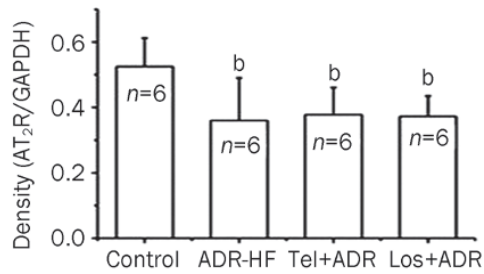

Figure 5. The protein expression levels of the Mas receptor $(A), A T_{1} R(B)$, and $A T_{2} R(C)$ in cardiac tissues at the end of the study were determined by Western blotting. Amounts of Mas, $A T_{1} R$, and $A T_{2} R$ were expressed relative to the amount of $G A P D H$ in each sample. Controls=With normal saline injection; ADR-HF=Adriamycin-induced heart failure rats; Tel+ADR=Telmisartan plus Adriamycin-treated rats; Los+ADR=Losartan plus Adriamycintreated rats. Data are expressed as mean \pm SD. ${ }^{b} P<0.05,{ }^{c} P<0.01$ vs control group. ${ }^{f} P<0.01$ vs ADR-HF.

ological conditions, plasma concentrations of Ang-(1-7) are similar to the plasma levels of Ang $\mathrm{II}^{[25]}$. Conversely, under some pathological conditions, eg, untreated essential hypertensive subjects, the urinary concentrations of Ang-(1-7) is lower than in normotensive controls, but chronic treatment with ARBs increases plasma levels of Ang-(1-7) 5- to 25-fold in both rats and humans ${ }^{[26]}$. Moreover, previous reports have suggested that Ang-(1-7) is cardioprotective in myocardial ischemia/reperfusion and heart remodeling after heart infarction or heat failure ${ }^{[27,28]}$. In our study, the plasma Ang-(1-7) level was significantly lowered by ADR treatment. Surprisingly, treatment with either telmisartan or losartan resulted in increases in plasma Ang-(1-7) compared with the untreated ADR-HF group (both $P<0.05$ ). Based on the current results, we postulate that endogenous Ang-(1-7) could be a positive physiological protector for the heart, possibly mediating the beneficial effects of ARBs for ADR-induced heart failure.

$\mathrm{AT}_{1} \mathrm{R}$ and $\mathrm{AT}_{2} \mathrm{R}$ both belong to the family of $\mathrm{G}$ protein-coupled receptors, but they share only a $32 \%-34 \%$ identity at the amino acid level ${ }^{[9]} . \mathrm{AT}_{1} \mathrm{R}$ is widely distributed in the adrenal glands, kidneys, blood vessels, heart, brain, liver, bronchial tissue and other tissues ${ }^{[9]}$. After stimulation with Ang II, $\mathrm{AT}_{1} \mathrm{R}$ can cause vasoconstriction, $\mathrm{Na} / \mathrm{H}_{2} \mathrm{O}$ reabsorption, inflammatory response, hypertrophy, hyperplasia, cell proliferation and so on ${ }^{[9]}$. It has been reported that the increase in oxidative stress coexists with $\mathrm{AT}_{1} \mathrm{R}$ upregulation in models of hypertension $^{[29]}$. The data presented in this study showed that in the ADR-HF group, expression of the $\mathrm{AT}_{1} \mathrm{R}$ was upregulated compared with the control group $(P<0.05)$. This phenomenon may be due to enhanced oxidative stress and an activated RAS localized to cardiac tissue during heart failure. In addition, in the telmisartan- or losartan-treated rat heart, expression of the $\mathrm{AT}_{1} \mathrm{R}$ returned to control values, suggesting that the inhibitory effect of $\mathrm{ARBs}$ on the $\mathrm{AT}_{1} \mathrm{R}$ contributes critically to their protective effect in ADR-induced heart failure.

The $\mathrm{AT}_{2} \mathrm{R}$ is localized in numerous embryonic and neonatal tissues, but its expression declines rapidly after birth and is then restricted to certain organs such as the adrenal glands, ovary, heart, brain, uterus, vascular endothelium, kidney and lung ${ }^{[9]}$. Stimulation of the $\mathrm{AT}_{2} \mathrm{R}$ can cause vasodilation, a reduced inflammatory response, apoptosis, anti-proliferation and anti-oxidative stress ${ }^{[9]}$. Previous studies demonstrated that the amount of $\mathrm{AT}_{2} \mathrm{R}$ was negatively correlated with LVIDd and positively correlated with LVEF, suggesting that left ventricular dysfunction was associated with decreased expression of myocardial $\mathrm{AT}_{2} \mathrm{R}$ protein ${ }^{[30]}$. The Mas receptor is also a $G$ protein-coupled receptor, and it is widely expressed in some tissues ${ }^{[31]}$. Importantly, it is the receptor for Ang-(1-7) ${ }^{[13]}$. Recently, new evidence has suggested that Ang-(1-7) acts via $\mathrm{NO} / \mathrm{cGMP}$ to prevent the Ang II-induced translocation of the nuclear factor of activated $\mathrm{T}$ cells in cardiomyocytes ${ }^{[32]}$. Moreover, in both in vitro and in vivo conditions, Mas receptordeficient mice showed impairment of cardiac functions such as hypotonia of myocardial contraction and reduction of cardiac output ${ }^{[13]}$. Our study showed that in ADR-treated rats, both the mRNA and protein expression of the $\mathrm{AT}_{2} \mathrm{R}$ and Mas receptor were downregulated. However, treatment with ARBs did not restore the expression of the $\mathrm{AT}_{2} \mathrm{R}$ and Mas, suggesting that although the decreases in the expression level of the $\mathrm{AT}_{2} \mathrm{R}$ and Mas receptor may be characteristics of ADR-induced heart failure, the cardio-protection of ARBs is not mediated by the $\mathrm{AT}_{2} \mathrm{R}$ and Mas receptor.

In summary, our results confirmed that ARBs are beneficial for ADR-induced heart failure and demonstrated that the influences of $A R B s$ on circulating Ang-(1-7) levels and $A_{1} R$ expression in cardiomyocytes may contribute to the cardioprotection of ARBs in this model. Our data may add new evidence to this research field and provide new mechanisms for applications of ARBs to reduce cardiotoxicity in ADR-treated patients.

\section{Acknowledgements}

This work was supported by the National Natural Science Foundation of China (№ 30770890). 


\section{Author contribution}

Xin-zheng LU, Ke-jiang CAO and Jun-HUANG designed research; Wen-na ZONG, Xiao-hui YANG, Xiu-mei CHEN, Hong-juan HUANG, Hong-jian ZHENG and Xiao-yi QIN performed research; Yong-hong YONG contributed new analytical tools and reagents; Wen-na ZONG analyzed data; Wen-na ZONG and Xin-zheng LU wrote the paper.

\section{References}

1 Singal PK, Li T, Kumar D, Danelisen I, lliskovic N. Adriamycin-induced heart failure: mechanism and modulation. Mol Cell Biochem 2000; 207: 77-86.

2 Singal PK, Iliskovic N. Doxorubicin-induced cardiomyopathy. N Engl J Med 1998; 339: 900-5.

3 Sia YT, Lapointe N, Parker TG, Tsoporis JN, Deschepper CF, Calderone A, et al. Beneficial effects of long-term use of the antioxidant probucol in heart failure in the rat. Circulation 2002; 105: 2549.

4 Ezhilan RA, Rajesh R, Rajaprabhu D, Meena B, Ganesan B, Anandan R. Antioxidant defense of glutamine on myocardial antioxidant status in adriamycin-induced cardiomyopathy in rats. J Cell Animal Biol 2008; 2: 107-11.

5 Dhalla NS, Wang X, Sethi R, Das PK, Beamish RE. Beta-adrenergic linked signal transduction mechanisms in failing hearts. Heart Failure Rev 1997; 2: 55-65.

6 Takeuchi M, Lee JD, Shimizu H, Ueda T. Effects of long-term oral treatment with selective vasopressin $\mathrm{V} 2$ receptor antagonist (OPC31260) on adriamycin-induced heart failure in rats. Int J Cardiol 2006; 108: 231-6.

7 Lu L, Wu W, Yan J, Li X, Yu H, Yu X. Adriamycin-induced autophagic cardiomyocyte death plays a pathogenic role in a rat model of heart failure. Int J Cardiol 2009; 134: 82-90.

8 Schmieder RE, Hilgers KF, Schlaich MP, Schmidt BMW. Reninangiotensin system and cardiovascular risk. Lancet 2007; 369: 1208-19.

9 Hebert PR, Foody J, Hennekens $\mathrm{CH}$. The renin-angiotensin system: the role of inhibitors, blockers, and genetic polymorphisms in the treatment and prevention of heart failure. Curr Vasc Pharmacol 2003; 1: 33-9.

10 Jickling GC, Xu H, Stamova B, Ander BP, Zhan X, Tian Y, et al. Signatures of cardioembolic and large-vessel ischemic stroke. Ann Neurol 2010; 68: 681-92.

11 Santos RA, Ferreira AJ, Simoes ESAC. Recent advances in the angiotensin-converting enzyme 2-angiotensin(1-7)-Mas axis. Exp Physiol 2008; 93: 519-27.

12 Iwai M, Horiuchi M. Devil and angel in the renin-angiotensin system: ACE-angiotensin II-AT1 receptor axis vs. ACE2-angiotensin-(1-7)-Mas receptor axis. Hypertens Res 2009; 32: 533-6.

13 Santos RA, Simoes e Silva AC, Maric C, Silva DM, Machado RP, de Buhr I, et al. Angiotensin-(1-7) is an endogenous ligand for the $G$ protein-coupled receptor Mas. Proc Natl Acad Sci U S A 2003; 100 : 8258-63.

14 Xu P, Costa-Goncalves AC, Todiras M, Rabelo LA, Sampaio WO, Moura MM, et al. Endothelial dysfunction and elevated blood pressure in MAS gene-deleted mice. Hypertension 2008; 51: 574-80.

15 Loot AE, Roks AJ, Henning RH, Tio RA, Suurmeijer AJ, Boomsma F, et al. Angiotensin-(1-7) attenuates the development of heart failure after myocardial infarction in rats. Circulation 2002; 105: 1548-50.

16 Iqbal M, Dubey K, Anwer T, Ashish A, Pillai KK. Protective effects of telmisartan against acute doxorubicin-induced cardiotoxicity in rats. Pharmacol Rep 2008; 60: 382-90.

17 Ibrahim MA, Ashour OM, Ibrahim YF, EL-Bitar HI, Gomaa W, AbdelRahim SR. Angiotensin-converting enzyme inhibition and angiotensin AT1-receptor antagonism equally improve doxorubicin-induced cardiotoxicity and nephrotoxicity. Pharmacol Res 2009; 60: 373-81.

18 Cadeddu C, Piras A, Mantovani G, Deidda M, Dessi M, Madeddu $C$, et al. Protective effects of the angiotensin II receptor blocker telmisartan on epirubicin-induced inflammation, oxidative stress, and early ventricular impairment. Am Heart J 2010; 160: 487.e1-7.

19 Arozal W, Watanabe K, Veeraveedu PT, Thandavarayan RA, Harima M, Sukumaran V, et al. Effect of telmisartan in limiting the cardiotoxic effect of daunorubicin in rats. J Pharm Pharmacol 2010; 62: 177683.

20 Xing SS, Bi XP, Tan HW, Zhang Y, Xing QC, Zhang W. Overexpression of interleukin-18 aggravates cardiac fibrosis and diastolic dysfunction in fructose-fed rats. Mol Med 2010; 16: 465-70.

21 Kjaergaard AD, Bojesen SE, Johansen JS, Nordestgaard BG. Elevated plasma YKL-40 levels and ischemic stroke in the general population. Ann Neurol 2010; 68: 672-80.

22 Correale J, Villa A. Role of CD8+ CD25+ Foxp3+ regulatory T cells in multiple sclerosis. Ann Neurol 2010; 67: 625-38.

23 Fan Y, Shen F, Frenzel T, Zhu W, Ye J, Liu J, et al. Endothelial progenitor cell transplantation improves long-term stroke outcome in mice. Ann Neurol 2010; 67: 488-97.

24 Kang YJ, Digicaylioglu M, Russo R, Kaul M, Achim CL, Fletcher L, et al. Erythropoietin plus insulin-like growth factor-I protects against neuronal damage in a murine model of human immunodeficiency virus-associated neurocognitive disorders. Ann Neurol 2010; 68: 342-52.

25 Joyner J, Neves LA, Granger JP, Alexander BT, Merrill DC, Chappell MC, et al. Temporal-spatial expression of ANG-(1-7) and angiotensinconverting enzyme 2 in the kidney of normal and hypertensive pregnant rats. Am J Physiol Regul Integr Comp Physiol 2007; 293: R169-R177.

26 Dilauro M, Burns KD. Angiotensin-(1-7) and its effects in the kidney. ScientificWorldJournal 2009; 9: 522-35.

27 Grobe JL, Mecca AP, Lingis M, Shenoy V, Bolton TA, Machado JM, et al. Prevention of angiotensin II-induced cardiac remodeling by angiotensin-(1-7). Am J Physiol-Heart Circ Physiol 2007; 292: H736$\mathrm{H} 743$.

28 Loot AE, Roks AJM, Henning RH, Tio RA, Suurmeijer AJH, Boomsma F, et al. Angiotensin-(1-7) attenuates the development of heart failure after myocardial infarction in rats. Circulation 2002; 105: 1548-53.

29 Reja V, Goodchild AK, Phillips JK, Pilowsky PM. Upregulation of angiotensin AT1 receptor and intracellular kinase gene expression in hypertensive rats. Clin Exp Pharmacol Physiol 2006; 33: 690-5.

30 Matsumoto T, Ozono R, Oshima T, Matsuura H, Sueda T, Kajiyama $\mathrm{G}$, et al. Type 2 angiotensin II receptor is downregulated in cardiomyocytes of patients with heart failure. Cardiovasc Res 2000; 46: 73-81.

31 Katovich MJ, Grobe JL, Raizada MK. Angiotensin-(1-7) as an antihypertensive, antifibrotic target. Curr Hypertens Reports 2008; 10 : 227-32.

32 Gomes ER, Lara AA, Almeida PW, Guimaraes D, Resende RR, Campagnole-Santos MJ, et al. Angiotensin-(1-7) prevents cardiomyocyte pathological remodeling through a nitric oxide/guanosine 3',5'-cyclic monophosphate-dependent pathway. Hypertension 2010; 55: 153-60. 